\title{
Success for All: Professor Slavin and the Improvement of Evidence-Based Schools and Its Enlightenment to China
}

\author{
Longjun Zhou, ${ }^{1,2} \mathrm{Hui} \mathrm{Gu}{ }^{3}$
}

1. Jiangsu Second Normal University, Nanjing 211200, Jiangsu, China

2. Engineering Research Center of Digital Learning Support Technology, Ministry of Education, Changchun 130000, Jilin, China

3. Nanjing Normal University, Nanjing 210024, Jiangsu, China

\begin{abstract}
Success for All (SFA) is a school improvement project promoted by the team of Professor Robert Slavin of Johns Hopkins University. This paper reviewed the development process of SFA and analyzed its characteristics. By comparing with China's "New Basic Education" project, we summarized the reference value of SFA for China, and further discussed the possible path of China's evidence-based school improvement.
\end{abstract}

Best Evidence in Chinese Education 2021; 8(1):1029-1040.

Doi: 10.15354/bece.21.or35.

How to Cite: Zhou, L., Gu, H. (2021). Success for All: Professor Slavin and the improvement of evidence-based schools and its enlightenment to China. Best Evidence in Chinese Education, 8(1):1029-1040.

Keywords: Robert Edward Slavin, Success for All, Evidence-Based School Improvement, Enlightenment to China

About Author: Hui Gu, School of Education Science, Nanjing Normal University, Nanjing 210024, Jiangsu, China. Email: gu_nnu@163.com

Correspondence to: Longjun Zhou, Jiangsu Second Normal University, Nanjing 211200, Jiangsu, China; Engineering Research Center of Digital Learning Support Technology, Ministry of Education, Changchun 130000, Jilin, China. Email: 294437034@qq.com

Conflict of Interests: None. 
$\mathrm{H}$ ELPING schools, especially weak schools, improve the efficiency of education and teaching, and promote the quality of teaching is an important theme in educational research and practice. Over the years, with the joint efforts of researchers and practitioners, the improvement projects of some schools have achieved remarkable results. This includes "Success for All" (SFA) led by Robert Slavin of Johns Hopkins University, "Direct Instruction" (DI) of Siegfried Engelmann of the University of Illinois, and "The Accelerated Schools" of Henry Levin of Stanford University. They are all helping students, especially those with disadvantaged family backgrounds and poor grades, through which they have achieved remarkable results in improving students' reading, math, and language skills. However, researchers have noticed that what works well in some schools may not be applicable in others (Borman et. al., 2002). In order to avoid the bias of results caused by a single independent research, and to achieve the best plan for the evaluation of student ability, a non-profit social science research institution operated by the American Institutions for Research (AR) funded by the Office of Elementary and Secondary Education of the US Department of Education - Comprehensive School Reform Quality (CSRQ) evaluated and compared the effectiveness and quality of 22 comprehensive school reforms. It was found that SFA relied on the wide coverage of schools $(1,200)$ and applicable age (preschool-7th grade), the most research designs (41), the most valid conclusions (34), and a clear effect size ( $d=$ 0.18 ), thus getting the best evaluation (Slavin, 2007).

Chinese educators have also contributed greatly to the school improvement. As a successful school improvement project, SFA was the most important educational research and practice legacy of Professor Slavin. It undoubtedly provided an important reference for the work of Chinese colleagues. This paper will discuss the path of China's evidence-based school improvement on the basis of reviewing and summarizing the experience of SFA, hoping to find some new ideas for the reform and development of Chinese education.

\section{Success for All: How Professor Slavin Promoted School Improvement Based on Evidence}

Since 1986, Professor Slavin's team has been invited by Baltimore City Public Schools to develop a project that can ensure the success of all poor children, which became the origin of the SFA project. Professor Slavin and his team believed that a good school can

(C) 2021 Insights Publisher. All rights reserved.

Creative Commons Non Commercial CC BY-NC: This article is distributed under the terms of the Creative Commons Attribution-NonCommercial 4.0 License (http://www.creativecommons.org/licenses/by$\mathrm{nc} / 4.0 /$ ) which permits non-commercial use, reproduction and distribution of the work without further permission provided the original work is attributed by the Insights Publisher. 
develop more "adversity-resistant students", thereby helping those students with poor family backgrounds to obtain "counter-attack" in performance. However, helping students to read is an early key factor for students to achieve academic success. Therefore, the research team started from Cooperative Reading and gradually developed a school improvement plan that can provide comprehensive guidance for students from preschool to 7 th-grade. Early interventions include ability grouping in the form of teaching organization-aka Joplin Plan (Slavin, 1987; Gutierrez \& Slavin, 1992), classroom management strategies (Evertson et al, 2000), and one-to-one student reading improvement program (Pinnell et al., 1988; Pinnell et al., 1994), teacher professional development path (Perry et. al., 1999); etc. These actions were integrated into the early SFA plan.

The early intervention has achieved obvious results. Since then, the research team has turned its attention to a wider range of areas. On the one hand, the SFA plan began to pay attention to the impact of related interventions on second language acquisition. Because when teaching children from poor families, a large number of students come from families whose mother tongue is not English, it has partially demonstrated the positive effect of the SFA program on bilingual learning. At the same time, when teaching reading, learning phonics \& phonological awareness, which is an important part of English learning like Chinese phonetic alphabet (Pin Yin in Chinese), is extremely conducive to the rapid grasp of English pronunciation and writing. Studies have found that this has a significant positive impact on the English learning of Spanish, Colombian, Mexican and Chinese students (Calderon et al., 1998; Cheung \& Slavin, 2005; Slavin \& Madden, 1999; Ross et al., 1996). In addition, Borman et al. also conducted a longitudinal follow-up survey of Baltimore school students and found that by the eighth grade, these students' performance in standardized reading was still significantly better than the early control students (Borman et al., 2003). On the other hand, the SFA project team also explored the auxiliary teaching and evaluation of electronic software. The research team used Reading Reel and Alphie's Alley. The former is software that helps students to learn vocabulary in the form of animation, and the latter is software that helps teachers to plan lessons and evaluate students. After three sets of comparative experiments, it was found that the students who used Reading Reel and Alphie's Alley performed better than those who only participated in the SFA program and only participated in the SFA tutor guidance (Chambers et al., 2007; Chambers et al., 2005a; Chambers et al. al., 2005b). So far, SFA has achieved great success. It has become one of the most effective and evidence-based education-based school improvement programs in the United States.

After CSQR integrated 41 SFA experiments, it is found that the effect size of SFA on students is $d=0.18$. Although 0.18 was a small effect size, in the field of education, large-scale random intervention programs such as SFA could achieve an effect size of about 0.2 was already a very exciting result. This showed that the effect of SFA was significant, and its actions could provide strong evidence for the formulation of education policies. The success of SFA is largely due to the design, implementation and improvement of each of its interventions based on scientific evidence; and in the process of continuous iteration, a robust, systematic, high promotion value, and effective 
intervention method has been formed. In this way, more schools will benefit in a larger scale. These proven methods include:

\section{Flexible Class Schedule and Class Placement Mode}

Based on the research of Evertson et al. (2000), the SFA plan uses 90 minutes as a course unit to make the classroom rhythm compact and efficient. What teachers have to do is to improve class management strategies and use time efficiently. However, due to the large differences in the abilities of students in a class, efficient teaching is challenged. Therefore, students in the SFA program should pass a test before participating in the reading program and be reclassified. This type of teaching has the following advantages: First, teachers can better teach per their aptitude to meet the different learning needs of students with different abilities. Second, teachers do not need to group in class for separate guidance when teaching, which not only improves the rhythm of the course, but also increases the efficiency of the class. Third, the class size after re-grouped is smaller than the original class size, which helps teachers pay more attention to students and accumulate teaching experience and skills.

\section{Rich and Diverse Teaching Resources}

In order to meet the different reading needs of students from preschool to seventh grade, SFA has designed different curriculum plans. In the teaching materials book provided by SFA, these activities will be integrated according to the physical and mental laws of student development, and the key points, goals, and maxims of teaching will be put forward. It provides teachers with a set of teaching systemic materials for almost all the ability development needs of students. In the pre-school stage, these materials were called Curiosity Corner and Kinder Corner by the SFA research team; after that, SFA provided Reading Roots, Reading Wings and Reading Edge course materials for the beginner, intermediate and middle school students, respectively. In addition to providing teaching materials and books, SFA also provides comprehensive guidance on activities corresponding to the development needs of students, student evaluation record sheets after teaching, evaluation methods and evaluation questions, which provide teachers with direction guidance.

\section{Professional “Coordinator” Guidance}

In order to realize the smooth development of the project, SFA has set up a project "coordinator", which mainly includes two roles: one is the facilitator for the entire project operation; the other is the tutor for coordinating courses, teachers, students, and equipment. A school generally has a facilitator, whose main job is to organize periodic student assessments, lectures and lectures, and teacher training, select the appropriate learning stage for students, and help teachers improve their work; etc. In this process, the coordinator is not an evaluator, supervisor or vice-principal, but a supporter of teacher development. Therefore, many coordinators themselves are excellent and ex- 
tremely experienced teachers. A school can have multiple tutors. When instructing students, they often adopt one-to-one guidance, assess students' progress, determine priority development abilities and teaching materials, combine class teaching, learn to read by reading, and actively communicate with class instructors.

\section{Emphasize Fairness and Full Participation}

According to the original purpose of the SFA plan, in order to promote educational equity, helping students from poor families to develop better. First of all, SFA plans to conduct school selection before officially introducing schools. It generally selects disadvantaged schools that are dominated by non-white students such as Latino or African descent. Secondly, before the school is ready to accept the plan, teachers will vote to decide whether to participate. It will only be introduced when more than $90 \%$ of school teachers show a positive attitude towards this plan. Finally, the school will inform the parents of the rules of the plan and sign an agreement to protect the parents' right to know the plan; if the parents refuse to participate, the children will not be included in the school improvement plan. These three steps ensure that all participants initially have a positive attitude to promote the complete operation of the entire program. After the plan is launched, SFA will also obtain parental support and participation through various methods such as home visits, sending text messages to parents, parent-child reading, and family-school activities.

\section{What Can We Learn? Enlightenment of Evidence- Based School Improvement in a Comparative Per- spective}

In the process of China's education reform and development, school improvement is also a task that all parties attach great importance to. In the process of long-term exploration, Chinese educators have also discovered some ways to improve schools with Chinese characteristics.

Among the many local school reforms in China, the most influential one with the most complete system and the longest continuous practice is undoubtedly the "new basic education" reform. For a long time, excessive emphasis on test scores has made it difficult to cultivate the talents China needs. This is the main problem that China's basic education has been widely criticized. In this regard, Professor Lan Ye from East China Normal University put forward the basic education reform idea of "new basic education" and put it into practice (Feng \& Xiang, 2018). In 1994, Professor Lan Ye began to construct the theory of "new basic education"; by 1999, it entered the stage of promotion and developmental research; so far, it has entered a stage of gradual enrichment and vigorous growth in theory and practice. The research and experiment of "new basic education" have gone through nearly 30 years. It has become a model of school improvement with far-reaching influence and Chinese characteristics. 
This project, starting from the full and complete development of "life", highlights the dominant position of learners, and builds a complete system of classroom teaching, teacher development, class construction, and school management. Its ultimate goal is to promote the healthy and comprehensive development of students. It is an educational reform that is jointly promoted by Chinese local researchers and front-line workers, combines educational theory and practical exploration, and meets the needs of cultivating new talents in the 21 st century (Ye, 1999). Such a change has impacted the traditional educational concepts and strengthened the student-centered view of teaching in a considerable range, through which a distinctive, flexible and effective teaching mode and curriculum system have formed. Eventually it became a representative project for the improvement of Chinese local schools in the new era (Liu, 2003). Similar to SFA, the experiments of "New Basic Education" are all educational reform projects based on school improvement. There are many similarities between the two in terms of value pursuit, implementation methods and research drive.

\section{First of all, both uphold the student-centered teaching concept, and make every student fully developed as the value pursuit.}

In terms of curriculum, SFA always focuses on the development of students, and strives to solve the reading problems of students in weak schools, so that students can increase students' enthusiasm and autonomy through group cooperation, thereby improving students' reading ability. Meanwhile, the SFA program will also set up different reading courses for students at different levels to achieve personalized reading teaching as much as possible. China's "New Basic Education" experiment also has a lot of measures focusing on individualized learning of students and helping disadvantaged schools and students. Both of them embody a strong value trend of emphasizing educational equity.

\section{Second, both have adopted a comprehensive reform ap- proach to advance, and attach importance to the partic- ipation of multiple subjects.}

The reform of the SFA model was originally intended to improve the reading level of the students in the lower grades of weak schools. However, with the advancement of experimental reforms, the SFA model not only includes reading teaching, but also involves the psychological aspects of students, and finally developed into an effective teaching paradigm for bilingual teaching and non-native English teaching. In order to promote school reform and ensure the effect of intervention, SFA has also formed a package plan including research support, teaching optimization, leadership improvement, and home-school cooperation. It has fully mobilized the power and resources of schools, families and communities. At the same time, with the support of the government and enterprises and other social forces, the participants have realized diversifica- 
tion. The "New Basic Education" experiment also showed such characteristics in the process of organization and implementation. Researchers in the theory of education system ecology represented by the American psychologist Bronfenbrenner (1979) believed that the development of human beings is affected by multiple environmental factors. Through mutual restriction and mutual connection among various elements, children's development and understanding will be enriched continuously. Both of these projects have achieved the joint participation of schools, families and communities, and the joint efforts of multiple parties have contributed to success.

\section{Third, both are based on full cooperation between scholars and schools, and school improvements imple- mented with the support of academic research.}

As mentioned earlier, during the implementation of SFA, Professor Slavin and his team provided solid research support for the reform of the school. This support is not only reflected in the provision of relevant teaching resources and teaching models for the implementation of reforms, but also in the implementation of recommendations and interventions based on research evidence. This ensures that relevant reforms can be carried out in the right direction, while also being able to adjust specific measures in a timely manner based on feedback. The "new basic education" was initiated by scholars when it was implemented. Starting from theoretical research and then promoting practical improvement, throughout the implementation process, a research-driven, theorypractice-combined approach was adopted. From this perspective, these two school improvement projects are different from the reform efforts carried out by the schools themselves, and both reflect obvious research-leading characteristics.

Although the two projects have the same characteristics as above, it is undeniable that there are also differences between the two. Although the "New Basic Education" is a far-reaching school improvement project in China, it has also made outstanding contributions to the reform of China's education. But so far, such efforts still suffer from insufficient scientific evidence, improper grasp of the model, unclear interpretation of the rules, and difficulty in popularizing experience. The reason for this is largely due to the fact that many Chinese school improvement projects, including "new basic education", are not based on scientific evidence, but rely more on experience and feelings. For a long time, in China's education reforms, the gradual empiricist reform model is often emphasized, that is, reforms are carried out in accordance with past experience and subjective wishes while ignoring scientific evidence (Zhang, 2007).

This makes it difficult for people to objectively judge the actual effect of a certain reform. Furthermore, due to the lack of scientific evidence, even if a certain reform achieves the expected results, we still cannot know exactly what factors have led to such a success under what conditions. Therefore, it is even more difficult to know to what extent such success reveals the scientific laws of education and teaching, and to what extent can it be promoted and valued. As a representative project of evidencebased school improvement, SFA may be able to provide us with reference to solve this 
problem in China. As an outstanding scholar of evidence-based education research and reform, Professor Slavin has spent his life exploring the methods and paths of evidencebased education. In the implementation of the SFA project, on the one hand, any intervention is based on the evidence of previous studies.

On the other hand, during the implementation of the project, rigorous experimental interventions were also implemented. So that researchers and practitioners can accurately grasp and evaluate the effect of project implementation and its mechanism of action. In this way, we can get rid of the chronic problem of empirical school improvement projects and help find more targeted and effective school reform measures. This is probably the most worthy place for Chinese schools to learn from.

\section{What Can We Do? Possible Approaches to China's Evidence-Based School Improvement}

From the perspective of the advancement and improvement process of SFA, research methodology based on educational experiments and quasi-experiments has become an important support for the reform of the program. In the reform, the use of evidence as the basis for selected programs will enable education to enter a virtuous circle of innovation, evaluation, and gradual improvement (Slavin, 2013). But it needs to be pointed out that due to the differences in national conditions and teaching conditions, when we learn from the experience of SFA, we first need to demonstrate the possibility of learning.

First, as far as the overall policy environment is concerned, China has issued a series of policy documents and emphasizes the application of evidence in the educational decision-making and reform process. However, we are not like the United States, requiring all important education reforms at the national level to be based on evidence and educational scientific research. As a result, many of the current decisions and reforms in China are still based on feelings, experience and even the consciousness of officials. Therefore, the scientific awareness and quality of educators need to be greatly improved.

Second, in terms of the implementation conditions of evidence-based school improvement, Chinese schools need to implement teaching in accordance with the national curriculum standards and syllabus during the teaching process. Therefore, the teaching autonomy of schools and teachers is greatly restricted. This makes the selection and implementation of intervention measures face more restrictions and difficulties in the process of promoting school improvement.

Third, because of the evidence-based research and reform of education, it is still a new thing for China. Therefore, there are deficiencies in the research staff and research level. There is also a lack of accurate and effective measurement tools suitable for the local area, which makes us have more difficulties in measurement and analysis to deal with in the process of carrying out evidence-based education reform.

This means that China must do something and not do something in the process of promoting evidence-based school improvement. In other words, it is necessary to 
explore the evidence-based school improvement road with Chinese characteristics based on the national conditions and education of the country.

(i) Whether they are policy makers, researchers, principals or frontline teachers, they all need to firmly establish a scientific outlook on development. In the reform and development of education, it is necessary to strengthen the awareness of evidence and truly achieve decision-making and teaching based on evidence. To achieve this, the government not only needs to further strengthen the requirements for evidence at the institutional level, but also requires researchers to change the style of study and vigorously strengthen empirical research; further, schools need to pay more attention to the acquisition and use of evidence in the reform process.

(ii) It is necessary to vigorously strengthen and promote educational experimental research in China. As far as the current research status of domestic school improvement is concerned, most of the research is still speculative research, and a small amount of empirical research is mostly statistical description and correlation analysis. Although this type of research can help understand the status quo and influencing factors of specific educational phenomena, it is difficult to conduct causal analysis. In education empirical studies without a control group, there would be a risk of biased estimation of the intervention effect (Cheung \& Slavin, 2016). To solve this problem, technically, the best way is to carry out rigorously designed experimental research. Only in this way can we provide more robust scientific evidence for school improvement based on more empirical research.

(iii) Efforts should be made to solve the problem of measurement methods and tools. In the process of school improvement in China, they are often good at reforming teaching and management models. However, due to the lack of authoritative and scientific measurement tools suitable for China conditions, many school improvement plans are unable to accurately report actual effects, influencing factors, and mechanism of action, so it is difficult to summarize their truly effective scientific laws. To solve this problem, the only way to increase scientific research is to develop measuring tools suitable for China's national and teachings conditions, and truly solve the problem of "can be measured and measured more accurately".

(iv) As mentioned earlier, successful evidence-based school improvement projects are the result of the cooperation of multiple parties. From the current reality of China's education reform and development, it can be known that the transformation of school improvement from experience-based to evidence-based cannot be accomplished with the efforts of one party alone. In terms of education evidence-based research and reform itself, it also requires close cooperation between researchers and practical work. It is impossible to obtain effective and robust evidence only by speculative "rocking chair" research, let alone evidence-based school improvement. Therefore, this must be a process from cooperation to win-win. In other words, the road of evidence-based 
school improvement must be the road of mutual dependence and promotion between theory and practice.

Professor Slavin and his team have presented a successful evidence-based school improvement path for educators around the world through the SFA project. Although the situation in different countries is not the same, the idea and path of evidencebased school improvement based on scientific research to promote the achievement of reform goals has shown its universal value. This is especially important for a country like China that has long been accustomed to advancing reforms through experience. After decades of rapid economic development in China, its education reform, like reforms in other fields, has entered the "deep water zone." Under such circumstances, reforms based solely on experience have increasingly shown its risks. Relying on scientific evidence to promote reforms steadily has become the only way for China's education reform and development. This road is not easy, but it is full of hope. In this process, Professor Slavin's outstanding work in the field of evidence-based research will continue to guide the researchers and practitioners to move forward like a lighthouse!

We would like to commemorate the respected Professor Slavin with this article.

\section{References}

Borman, G.D., Hewes, G.M., Overman, L.T., \& Brown, S. (2002). Comprehensive school reform and student achievement. A Meta-Analysis. John Hopkins University, Baltimore. https://medicine.yale.edu/childstudy/res earch/Images/Borman\%20metaanalysis tcm943-22549.pdf

Borman, G.D., Hewes, G.M., Overman, L.T., \& Brown, S. (2003). Comprehensive school reform and achievement: A meta-analysis. Review of Educational Research, 73(2):125-230. DOI: https://doi.org/10.3102/0034654307300 2125

Bronfenbrenner, U. (1979). The Ecology of Human Development: Experiments by
Nature and Design. Cambridge, MA: Harvard University Press.

Calderón, M., Hertz-Lazarowitz, R., \& Slavin, R. (1998). Effects of bilingual cooperative integrated reading and composition on students making the transition from Spanish to English reading. The Elementary School Journal, 99(2):153-165. DOI: https://doi.org/10.1086/461920

Chambers, B., Abrami, P.C., Tucker, B.J., Slavin, R.E., Madden, N.A., Cheung, A., \& Gifford, R. (2005a). Computerassisted tutoring in Success for All: Reading outcomes for first graders. https://www1.successforall.org/wpcon- 
Zhou \& Gu. Success for All: Professor Slavin and the Enlightenment to China.

tent/uploads/2016/02/Computer_Tutor

11_20_05.pdf

Chambers, B., Cheung, A., Madden, N., Slavin, R., \& Gifford, R. (2007). Embedded multimedia: Using video to enhance reading outcomes in Success for All. In Effective Instruction for Struggling Readers K-6 (pp.37-54). Teachers College Press.

Chambers, B., Slavin, R.E., Madden, N.A., Cheung, A., \& Gifford, R. (2005b). Enhancing Success for All for Hispanic students: Effects on beginning reading achievement. Success for All Foundation.

https://files.eric.ed.gov/fulltext/ED4853 $\underline{50 . p d f}$

Cheung, A., \& Slavin, R.E. (2005). Effective reading programs for English language learners and other languageminority students. Bilingual Research Journal, 29(2):241-267. DOI:

https://doi.org/10.1080/15235882.2005. 10162835

Cheung, A.C., \& Slavin, R.E. (2016). How methodological features affect effect sizes in education. Educational Researcher, 45(5):283-292. DOI:

https://doi.org/10.3102/0013189X16656 $\underline{615}$

Evertson, C.M., Emmer, E.T., \& Worsham, M.E. (2003). Classroom management for elementary teachers (6th Edition). Boston: Allyn and Bacon.

Feng, B., \& Xiang, S. (2018). A Review of China's New Basic Education Research in the Past Fifteen Years: Based on the Statistical Analysis of China HowNet. Journal of Shanghai Educational Research, 37(10):5-10. [Chinese] DOI: https://doi.org/10.16194/j.cnki.311059/g4.2018.10.002

Gutierrez, R., \& Slavin, R.E. (1992). Achievement effects of the nongraded elementary school: A best evidence synthesis. Review of Educational Research,
62(4):333-376. DOI:

https://doi.org/10.3102/0034654306200 4333

Liu, D. (2003). The voice of the times of China's basic education reform - Lan Ye's thoughts on basic education reform. Educational Science Research, 14(6):912.

https://www.cnki.com.cn/Article/CJFD2 003-JYKY200306002.htm

Perry, N.E., Walton, C., \& Calder, K. (1999). Teachers developing assessments of early literacy: A community of practice project. Teacher Education and Special Education, 22(4):218-233. DOI: https://doi.org/10.1177/0888406499022 00404

Pinnell, G.S., DeFord, D.E., \& Lyons, C.A. (1988). Reading Recovery: Early intervention for at-risk first graders. Arlington, VA: Education Research Services, pp. 84.

Pinnell, G.S., Lyons, C.A., DeFord, D.E., Bryk, A.S., \& Seltzer, M. (1994). Comparing instructional models for the literacy education of high-risk first graders. Reading Research Quarterly, 29(1):839. DOI: https://doi.org/10.2307/747736

Ross, S.M., Nunnery, J. \& Smith, L.J. (1996). Evaluation of Title I Reading Programs: Amphitheater Public Schools, Year 1: 1995-96, Memphis: University of Memphis, Center for Research in Educational Policy.

Slavin, R.E. (1987). Ability grouping in elementary schools: Do we really know nothing until we know everything? Review of Educational Research, 57(3):347-350. DOI: https://doi.org/10.3102/0034654305700 $\underline{3347}$

Slavin, R.E. (2007). Comprehensive School Reform. Success for All Foundation.

Retrieved May 25, from https://www.successforall.org/wpcon- 
Zhou \& Gu. Success for All: Professor Slavin and the Enlightenment to China.

tent/uploads/2016/02/Comprehensive-

School-Reform.pdf

Slavin, R.E. (2013). Overcoming the four barriers to evidence-based education.

Education Week, 32(29):24.

https://www1.successforall.org/wp-

content/uploads/2016/02/Overcoming-

Four -Barriers-to-Evidence-Based-

Education-Education-Week.pdf

Slavin, R.E., \& Madden, N.A. (1999). Success for All/Roots \& Wings. Summary of Research on Achievement Outcomes.
https://files.eric.ed.gov/fulltext/ED4383 63.pdf

Ye, L. (1999). "New Basic Education” Exploratory Research Report Collection, Shanghai: Shanghai Sanlian Bookstore, pp. 18-21.

Zhang, Q. (2007). Follow evidence-based principles to formulate education policies. Journal of the Chinese Society of Education, 28(7):11-15. https://www.cnki.com.cn/Article/CJFD Total-ZJYX200707005.html

Received: 19 May 2021

Revised: 24 May 2021

Accepted: 26 May 2021 